\title{
Difference in transducin-like enhancer of split 1 protein expression between basal cell adenomas and basal cell adenocarcinomas - an immunohistochemical study
}

Yuzo Oyama ${ }^{1}$, Haruto Nishida ${ }^{1 *}$, Takahiro Kusaba', Hiroko Kadowaki ${ }^{1}$, Motoki Arakane ${ }^{1}$, Junpei Wada², Shogo Urabe ${ }^{2}$, Takashi Hirano ${ }^{3}$, Kenji Kawano ${ }^{4}$, Masashi Suzuki ${ }^{3}$, Shigeo Yokoyama ${ }^{1}$ and Tsutomu Daa'

\begin{abstract}
Background: Basal cell adenoma (BCA) and basal cell adenocarcinoma (BCAC) are benign and malignant, basaloid salivary gland neoplasms, respectively. These tumors show a dual-cell proliferation of inner luminal/ductal cells and outer abluminal/myoepithelial or basal cells. The only difference between them is defined as a malignant morphology such as invasion. Recently, the nuclear expression of $\beta$-catenin and a catenin beta-1 (CTNNB1) mutation were found in BCA. Transducin-like enhancer of split 1 (TLE1) belongs to the Groucho/TLE family, and it functions in the "off" state in the Wnt/ $\beta$-catenin signaling pathway. We hypothesized that if the dysregulation of the $\mathrm{Wnt} / \beta$-catenin signaling pathway could be attributed to the tumorigenesis of BCA/BCAC, there might be differences in TLE1 expression between BCA and BCAC.

Method: The study included 35 BCA and 4 BCAC cases. We performed immunohistochemistry to detect TLE1 and $\beta$ catenin and investigated the catenin beta-1 (CTNNB1) mutational profile among BCA and BCAC cases.

Results: In BCA, the expression of TLE1 was confined to luminal cells of glandular structures, in contrast to the expression of $\beta$-catenin in abluminal cells. The BCA cases harbored CTNNB1 gene mutations (12/35). In BCAC, luminal cell staining of TLE1 was identical to BCA in non-invasive areas (4/4) but indistinct in invasive areas (3/4). The BCAC cases were $\beta$-catenin positive for abluminal cells in both areas. The BCAC cases had CTNNB1 mutation (2/4) and the laser-captured microdissection allowed the separate collection of infiltrative and non-infiltrative areas to detect the same mutation.
\end{abstract}

Conclusions: Immunohistochemical analysis for TLE1 can identify BCA and BCAC by luminal cell staining difference, especially indistinct luminal cell expression for TLE1 in invasive areas of BCAC. Moreover, TLE1 can be luminal/ductal cell markers.

Keywords: TLE1, Basal cell adenoma, Basal cell adenocarcinoma, $\beta$-catenin

\footnotetext{
* Correspondence: nharuto@oita-u.ac.jp

1 Department of Diagnostic Pathology, Faculty of Medicine, Oita University,

1-1, Idaigaoka, Hasama-machi, Yufu 879-5593, Japan

Full list of author information is available at the end of the article
}

(c) The Author(s). 2018 Open Access This article is distributed under the terms of the Creative Commons Attribution 4.0 International License (http://creativecommons.org/licenses/by/4.0/), which permits unrestricted use, distribution, and reproduction in any medium, provided you give appropriate credit to the original author(s) and the source, provide a link to the Creative Commons license, and indicate if changes were made. The Creative Commons Public Domain Dedication waiver (http://creativecommons.org/publicdomain/zero/1.0/) applies to the data made available in this article, unless otherwise stated. 


\section{Background}

A basal cell adenoma (BCA) is a benign salivary gland basal cell neoplasm $(\mathrm{BCN})$ that shows a dual-cell proliferation of inner luminal/ductal cells and outer abluminal/ myoepithelial or basal cells [1]. It has tubular, solid, nested, trabecular, and membranous growth with nuclear palisading [1]. Currently, catenin beta-1 (CTNNB1) gene mutations are exclusively found in BCA [2]. The nuclear expression of $\beta$-catenin is considered a characteristic feature of BCA because other salivary gland tumors rarely show nuclear staining [2]. In the presence of Wnt signal stimulation or an activating CTNNB1 gene mutation, $\beta$-catenin stabilizes and moves into the nucleus and interacts with T-cell factor (TCF)/lymphoid enhancer factor (LEF), which represents the "on" state of the Wnt/ $/$-catenin signaling pathway and leads to an increase in the transcription of the target gene associated with the pathway [3].

A basal cell adenocarcinoma (BCAC) is a malignant salivary gland $\mathrm{BCN}$ that possesses dual-cell proliferation similar to BCA [4]. Many authors differentiate BCAC from $\mathrm{BCA}$ by their malignant morphological features, such as invasion into surrounding tissues and perineural and angiolymphatic invasion [4-8]. Although $\mathrm{BCAC}$ is recognized as the malignant counterpart of $\mathrm{BCA}$, it is difficult to distinguish $\mathrm{BCAC}$ from $\mathrm{BCA}$ in surgical pathology practice. Several studies have attempted to identify characteristic immunohistochemical markers for the diagnosis of BCAC [5-8]. In other aspects, BCAC is generally recognized to have "low-grade malignancy" in terms of good overall survival [9]; however, high-grade cases of BCAC (9\%), some frequent recurrent cases (16.7-50\%), and some fatal cases $(2-5.6 \%)$ presented by several authors indicate the necessity for differentiating between $\mathrm{BCA}$ and $\mathrm{BCAC}[5,7,9,10]$. These findings suggest that there is some heterogeneity in biological behavior among $\mathrm{BCAC}$ cases.

Transducin-like enhancer of split 1 (TLE1) is a member of the Groucho (ortholog of Drosophila)/TLE gene family located at chromosome 9q21.32 and acts as a transcriptional corepressor [11]. The association of TLE1 and tumors was first detected in synovial sarcomas through gene expression profiling, and TLE1 was found to be profoundly involved in the Wnt/ $\beta$-catenin signaling pathway in synovial sarcomas $[12,13]$. Furthermore, TLE1 expression was associated with better prognosis in gastric cancer and human epidermal growth-factor receptor 2 (HER2)-positive or triple-negative breast cancer, and the clinical significance of the expression profile of TLE1 in several carcinomas was recently reported [11, 14]. To the best of our knowledge, there are no relevant reports regarding TLE1 expression in salivary gland neoplasms.

During the absence of the Wnt signal and impeded migration of $\beta$-catenin to the nucleus, TLE interacts with TCF/LEF and histone deacetylase (HDAC) instead of $\beta$-catenin and functions to repress the transcription of Wnt target genes, representing the "off" state of the Wnt/ $\beta$-catenin signaling pathway [15]. We hypothesized that if the dysregulation of the $\mathrm{Wnt} / \beta$-catenin signaling pathway could be attributed to the tumorigenesis of $\mathrm{BCA} / \mathrm{BCAC}$, there might be differences in TLE1 expression between $\mathrm{BCA}$ and $\mathrm{BCAC}$. This is the first report on TLE1 expression from the perspective of $\mathrm{Wnt} / \beta$-catenin signaling. Therefore, we performed immunohistochemical analyses of TLE1 and $\beta$-catenin and conducted a mutational analysis of the CTNNB1 gene in BCA and BCAC cases to identify an approach to differentiate $\mathrm{BCA}$ from $\mathrm{BCAC \text {. }}$

\section{Methods}

\section{Case selection}

This study was approved by the institutional review board of Oita University Hospital and Oita Prefecture Hospital. Thirteen-nine cases were retrieved from the archives of Oita University Hospital and Oita Prefecture Hospital. We reviewed their hematoxylin-eosin (HE) stained specimens according to the World Health Organization classification of head and neck tumors $[1,4]$. The study cases included $35 \mathrm{BCA}$ and $4 \mathrm{BCAC}$ cases. The clinicopathological findings of the patients are summarized in Table 1 (BCA) and Table 2 (BCAC). In BCA cases, the mean patient age was 65.4 years (range, 35-89 years), and the mean lesion size was $22.8 \mathrm{~mm}$ (range, $8-60 \mathrm{~mm}$ ). There was no sex predilection (male:female $=16: 19$ ), and the lesions occurred mainly in the parotid gland (parotid gland, 33 cases; submandibular gland, 2 cases). Additionally, no recurrence was noted (follow-up period: 0.5 month to 13 years). In $\mathrm{BCAC}$ cases, the mean patient age was 55.3 years (range, 24-70 years), and the mean lesion size was $32.0 \mathrm{~mm}$ (range, $15-53 \mathrm{~mm}$ ). There was a female predilection (male:female $=0: 4)$, and the lesions occurred solely in the parotid gland (parotid gland, 4 cases). None of the cases showed recurrence (follow-up period: 1 month to 5 years).

\section{Immunohistochemistry and analysis}

For immunostaining, we used the standard streptavidinbiotin complex method (SAB-PO kit; Nichirei, Tokyo, Japan). After cutting sections $(2 \mu \mathrm{m})$ from formalin-fixed paraffin embedded (FFPE) tissues were deparaffinized and rehydrated with xylene, alcohol, and tap water. Endogenous peroxidase was inactivated by $3 \%$ hydrogen peroxide. Next, heat epitope-induced retrieval was carried out according to primary antibody conditioning $\left(121{ }^{\circ} \mathrm{C}, 15 \mathrm{~min}\right)$. After antigen retrieval, blocking was performed, and the slides were incubated with primary antibodies (Table 3). Next, the slides were immersed with biotin-labeled anti-mouse or anti-rabbit antibodies and streptavidin peroxidase, visualized with diaminobenzidine, and counterstained with hematoxylin. Each 
Table 1 Clinicopathological information of the 35 basal cell adenoma cases

\begin{tabular}{|c|c|c|c|c|c|c|c|c|c|}
\hline Case No. & Sex & Origin & $\begin{array}{l}\text { Size } \\
(\mathrm{mm}) \\
\end{array}$ & $\begin{array}{l}\text { TLE1 } \\
\text { (luminal cell) }\end{array}$ & $\begin{array}{l}\beta \text {-catenin } \\
\text { (abluminal cell) }\end{array}$ & Ki67 & $\begin{array}{l}\text { Mitosis } \\
(/ 10 \mathrm{HPF}) \\
\end{array}$ & CTNNB1 mutation & $\begin{array}{l}\text { Follow-up } \\
\text { (Months) }\end{array}$ \\
\hline 1 & $\mathrm{~F}$ & $P$ & 11 & ++ & - & $3.4 \%$ & $1 / 10$ & - & 6 \\
\hline 2 & M & $P$ & 20 & ++ & ++ & $1.1 \%$ & $1 / 10$ & + & 6 \\
\hline 3 & $\mathrm{~F}$ & $P$ & 10 & + & ++ & $1 \%$ & $1 / 10$ & - & 2 \\
\hline 4 & M & $P$ & 20 & ++ & + & $1.3 \%$ & $0 / 10$ & + & 6 \\
\hline 5 & $\mathrm{~F}$ & $P$ & 16 & ++ & ++ & $1.1 \%$ & $0 / 10$ & + & 25 \\
\hline 6 & M & $P$ & 30 & ++ & - & $1.9 \%$ & $1 / 10$ & - & 32 \\
\hline 7 & $\mathrm{~F}$ & $P$ & 30 & ++ & - (cytoplasm+) & $3 \%$ & $1 / 10$ & - & 38 \\
\hline 8 & $\mathrm{~F}$ & $P$ & 20 & ++ & ++ & $0.5 \%$ & $0 / 10$ & - & 1 \\
\hline 9 & M & $P$ & 10 & ++ & ++ & $0.4 \%$ & $1 / 10$ & - & 38 \\
\hline 10 & M & P & 20 & ++ & + & $1.1 \%$ & $1 / 10$ & + & 12 \\
\hline 11 & $\mathrm{~F}$ & P & 20 & + & - & $1.7 \%$ & $0 / 10$ & - & 43 \\
\hline 12 & $M$ & P & 20 & ++ & ++ & $1.5 \%$ & $0 / 10$ & - & 1 \\
\hline 13 & $F$ & P & 8 & + & + & $1.1 \%$ & $1 / 10$ & - & 28 \\
\hline 14 & $\mathrm{~F}$ & P & 35 & - & - & $1.0 \%$ & $0 / 10$ & - & 76 \\
\hline 15 & $F$ & P & 26 & + & ++ & $1.3 \%$ & 0/10 & - & 18 \\
\hline 16 & $M$ & $S$ & 44 & + & - & $0.9 \%$ & $3 / 10$ & - & 18 \\
\hline 17 & $F$ & P & 10 & ++ & ++ & $1.0 \%$ & $1 / 10$ & + & 141 \\
\hline 18 & $\mathrm{~F}$ & P & 15 & + & + & $2.3 \%$ & $1 / 10$ & - & 100 \\
\hline 19 & $F$ & P & 20 & + & ++ & $1.0 \%$ & $1 / 10$ & - & 7 \\
\hline 20 & $\mathrm{~F}$ & $P$ & 60 & + & + & $2.4 \%$ & $0 / 10$ & + & 12 \\
\hline 21 & $F$ & $P$ & 25 & + & ++ & $1.5 \%$ & $0 / 10$ & + & 65 \\
\hline 22 & $M$ & P & 20 & - (old sample) & - & $1.0 \%$ & $0 / 10$ & + & 43 \\
\hline 23 & $\mathrm{~F}$ & S & 10 & ++ & - & $1.7 \%$ & $0 / 10$ & - & 4 \\
\hline 24 & F & $P$ & 20 & ++ & ++ & $1.7 \%$ & $0 / 10$ & + & 1 \\
\hline 25 & M & $P$ & 50 & ++ & - & $3.8 \%$ & $0 / 10$ & - & 1 \\
\hline 26 & M & $P$ & 30 & + & ++ & $1.6 \%$ & $1 / 10$ & - & 1 \\
\hline 27 & $\mathrm{~F}$ & $P$ & 16 & ++ & ++ & $2.5 \%$ & $1 / 10$ & - & 36 \\
\hline 28 & $M$ & $P$ & 31 & ++ & ++ & $2.7 \%$ & $1 / 10$ & - & 2 \\
\hline 29 & M & $P$ & 17 & + & ++ & $1.2 \%$ & $0 / 10$ & - & 0.5 \\
\hline 30 & M & $P$ & 20 & ++ & ++ & $2.2 \%$ & $1 / 10$ & - & 0.5 \\
\hline 31 & M & $P$ & 31 & ++ & ++ & $2.3 \%$ & $1 / 10$ & - & 0.5 \\
\hline 32 & M & $P$ & 20 & ++ & + & $0.8 \%$ & $1 / 10$ & + & NA \\
\hline 33 & F & $P$ & 25 & ++ & + & $1.4 \%$ & $1 / 10$ & + & 36 \\
\hline 34 & $\mathrm{~F}$ & $P$ & 23 & ++ & ++ & $1.8 \%$ & $1 / 10$ & - & 156 \\
\hline 35 & $M$ & P & 15 & + & + & $1.0 \%$ & $1 / 10$ & + & 2 \\
\hline
\end{tabular}

$P$ parotid gland, $\mathrm{S}$ submandibular gland, HPF high power field, NA not available

specimen was evaluated by 3 authors (YO, HN, and TD). For TLE1, staining of more than $30 \%$ of the tumor cells was considered positive, and the staining intensity was categorized as follows: strongly positive $(2+)$ or positive $(1+$, intensity as strong as that for normal salivary acinic or intercalated ductal cells). Nuclear staining was defined as positive for TLE1, $\beta$-catenin, and Ki67 staining. The Ki67 labeling index (LI) was calculated according to the number of Ki67-positive cells per 1000 cells. Cytoplasm staining was considered positive for $\alpha$ SMA staining. We used EMA and $\alpha$ SMA to identify the dual-cell differentiation of luminal and abluminal cells, respectively.

\section{CTNNB1 gene mutation analysis}

All tumor samples were analyzed for CTNNB1 gene mutations. We used 1-2 sections of $10-\mu \mathrm{m}$ FFPE-cut 
Table 2 Clinicopathological information of 4 basal cell adenocarcinoma cases

\begin{tabular}{|c|c|c|c|c|c|c|c|c|c|}
\hline Case No. & Sex & Origin & $\begin{array}{l}\text { Size } \\
(\mathrm{mm}) \\
\end{array}$ & TLE1 (nuclear) & $\beta$-catenin (nuclear) & Ki67 & $\begin{array}{l}\text { Mitosis } \\
\text { (/10HPF) }\end{array}$ & $\begin{array}{l}\text { CTNNB1 } \\
\text { Mutation }\end{array}$ & $\begin{array}{l}\text { Prognosis } \\
\text { (months) }\end{array}$ \\
\hline 1 & $F$ & $P$ & 20 & $\begin{array}{l}\text { luminal cell }++ \text {, but } \\
\text { indistinct at infiltrative areas }\end{array}$ & abluminal cell ++ & $9.0 \%$ & $3 / 10$ & + & Alive (18) \\
\hline 2 & F & $P$ & 40 & $\begin{array}{l}\text { luminal cell }+ \text {, but } \\
\text { indistinct at infiltrative areas }\end{array}$ & abluminal cell ++ & $4.7 \%$ & $4 / 10$ & + & Alive (24) \\
\hline 3 & $F$ & $P$ & 15 & luminal cell ++ & abluminal cell + & $5.3 \%$ & $4 / 10$ & - & Alive (60) \\
\hline 4 & $\mathrm{~F}$ & $P$ & 53 & $\begin{array}{l}\text { luminal cell }++ \\
\text { indistinct at infiltrative areas }\end{array}$ & abluminal cell ++ & $7.6 \%$ & $9 / 10$ & - & Alive (1) \\
\hline
\end{tabular}

$P$ parotid gland, HPF high-power field

specimens. Genomic DNA was extracted using the QIAmp DNA FFPE Tissue Kit (Qiagen, Hilden, Germany) according to the manufacturer's instructions. Exon 3 of the CTNNB1 gene was amplified by polymerase chain reaction (PCR) using primer sets (Table 4) and the AmpliTaq Gold fast PCR master mix (Applied Biosystems, Foster, CA). The PCR reaction protocol was as follows: $10 \mathrm{~min}$ at $95^{\circ} \mathrm{C}, 35$ cycles of $3 \mathrm{~s}$ at $96^{\circ} \mathrm{C}, 3 \mathrm{~s}$ at $60{ }^{\circ} \mathrm{C}$, and $5 \mathrm{~s}$ at $68{ }^{\circ} \mathrm{C}$, and $10 \mathrm{~s}$ at $72{ }^{\circ} \mathrm{C}$. We used $5 \mu \mathrm{l}$ of the PCR product as a template after treatment with $2 \mu \mathrm{l}$ of ExoSAP-IT ${ }^{\text {ma }}$ (Affymetrix, Santa Clara, CA) for PCR product cleanup. This reaction protocol was as follows: $15 \mathrm{~min}$ at $37^{\circ} \mathrm{C}$ and $15 \mathrm{~min}$ at $80^{\circ} \mathrm{C}$. The products were then sequenced using the BigDye ${ }^{\mathrm{TM}}$ Terminator v3.1 Cycle sequencing kit (Applied Biosystems). This protocol was as follows: $1 \mathrm{~min}$ at $96^{\circ} \mathrm{C}, 25$ cycles of $1 \mathrm{~s}$ at $96^{\circ} \mathrm{C}$ and $5 \mathrm{~s}$ at $50{ }^{\circ} \mathrm{C}$, and $2 \mathrm{~min}$ at $60{ }^{\circ} \mathrm{C}$. Forward or reverse primers were used for the sequencing reaction. The products were reacted with components of the DyeEX 2.0 Spin kit (Qiagen) to remove unincorporated dye terminators. Finally, sequence analysis was performed using the ABI PRISM 310 Genetic Analyzer (Applied Biosystems).

\section{Laser-capture microdissection}

Laser-capture microdissection (LCM) was applied for BCAC cases 1, 3, and 4. LCM was not applied in BCAC case 2 because there were few FFPE blocks. We collected 4-5 10- $\mu \mathrm{m}$ sections from the non-infiltrative or infiltrative areas of the tumor separately in a $0.5-\mathrm{ml}$ microtube using Leica LMD6000 (Leica Microsystems, Wetzlar, Germany). We then performed CTNNB1 gene mutation analysis for each specimen, as mentioned above.

\section{Results}

\section{TLE1 expression in normal salivary glands}

In normal salivary glands, acinic cells and intercalated ductal cells showed positive staining for TLE1 (Fig. 1).

\section{Histological findings of BCA and BCAC}

BCA cases displayed various growth patterns, such as tubular, solid, and trabecular structures, and the tumor cells were basaloid cells with pale eosinophilic cytoplasm and oval nuclei and showed few mitoses (Fig. 2a, d and g). For the BCAC cases, we confirmed that they all showed malignant morphology, such as infiltration into the surrounding salivary gland or adipose tissue. BCAC cases showing solid, tubular, and small nested structures; the tumor cells were basaloid cells, were nearly identical to those in BCA cases and showed slightly increased mitotic counts in infiltrative lesions (mean: 5.0/10 high power fields [HPF]) (Fig. 3a, a1, and a2). None of the BCAC cases possessed the characteristic histological features of adenoid cystic carcinoma (ACC), including cribriform growth patterns or angular nucleus of tumor cells; thus, we excluded ACC.

\section{Expression of TLE1 and other proteins by immunostaining in BCA and BCAC}

In $\mathrm{BCA}$ cases, the luminal cells of glandular structures were positive for TLE1 (33/35, 94\%) (Fig. 2b, e and h), and the abluminal cells were positive for $\beta$-catenin (26/35, 74\%) (Fig. 2c, $\mathrm{f}$ and i). In BCAC cases, TLE1 showed a luminal cell staining pattern $(4 / 4,100 \%)$ in non-infiltrative areas and indistinct or negative expression in infiltrative areas (Fig. $3 \mathrm{~b}$ and e). In BCAC, the abluminal cells were positive for $\beta$-catenin in both

Table 3 Primary antibodies and their conditioning in this study

\begin{tabular}{lllll}
\hline Antibody & Clone & Source & Dilution & Conditioning \\
\hline TLE1 & EPR9386 (2) & Abcam, Cambridge, UK & $1: 100$ & $\mathrm{pH} 9.0$ \\
$\beta$-catenin & 17C2 & Novocastra, Newcastle, UK & $1: 100$ & $\mathrm{pH} 6.0$ overnight \\
Ki67 & MIB-1 & DAKO, Santa Clara, USA & $1: 50$ & $\mathrm{pH} 6.0$ \\
aSMA & 1A4 & DAKO, Santa Clara, USA & $1: 100$ & \\
EMA & E29 & Nichirei Bioscience, Tokyo, Japan & Diluted & \\
\hline
\end{tabular}


Table 4 Primers sequence for CTNNB1 gene amplification used in this study

\begin{tabular}{ll}
\hline Primer & Sequence \\
\hline exon 3 F1 & 5'-GAACCAGACAGAAAAGCGGCTG-3' \\
exon 3 R1 & 5'-ACTCATACAGGACTTGGGAGG-3' \\
exon 3 F2 & 5'-AAAGTAACATTTCCAATCTACTAATG-3' \\
exon 3 R2 & 5'-AAAATCCCTGTTCCCACTCA-3' \\
\hline
\end{tabular}

areas (Fig. 3c and f), and the lining myoepithelial cells were positive for $\alpha \mathrm{SMA}$ in non-infiltrative areas but disappeared in infiltrative areas (Fig. $3 \mathrm{~d}$ and g). The Ki67 LI values were $1.6 \%$ (range, $0.4-3.8 \%$ ), 6.7\% (range, 4.7-9.0\%) for BCA, and BCAC cases, respectively.

\section{CTNNB1 gene mutation analysis}

DNA was successfully extracted in 39 cases. Among the BCA cases, 12 of 35 cases (34\%) had CTNNB1 gene mutations (11 cases showed I35T mutation (Fig. 2j) and 1 case showed H36P mutation. Among the BCAC cases, 2 with I35T mutation were detected. The mutation could be found in both infiltrative and non-infiltrative areas (Fig. $3 \mathrm{~h}$ and i).

\section{Discussion}

Wnt/ $\beta$-catenin signaling regulates postnatal development and regeneration of salivary gland and it is under in tight control because the dysregulation of it correlates with tumorigenesis $[16,17]$. TLE1 functions in the "off" state in the Wnt/ $\beta$-catenin signaling pathway [15]. In normal salivary glands, TLE1 showed staining for acinar and intercalated ductal cells, indicating that TLE1 expression was limited to "luminal" cells. $\beta$-catenin is generally expressed in the cytoplasm or cytomembrane in normal salivary grands [2], in contrast to the nuclear expression for TLE1, suggesting that salivary glands are normally in "off" state of Wnt/ $\beta$-catenin signaling. BCA showed positive TLE1 expression in the luminal cells of glandular structures, regardless of the tumor growth patterns. This result is consistent with the theory that BCA originates from intercalated duct lesions [7], and this finding might suggest that tumor cells maintain an "off" state of the Wnt/ $\beta$-catenin signaling pathway. The staining intensity of luminal cell staining of TLE1 in normal salivary gland and BCA cases was reduced with an increase in the age of the FFPE sample, possibly indicating that the staining was naive expression. Interestingly, the TLE1 and $\beta$-catenin staining patterns were clearly separated (TLE1 for luminal cells and $\beta$-catenin for abluminal cells). Kawahara et al. comprehensively analyzed the $\beta$-catenin expression profile in salivary gland neoplasms, which showed a nuclear expression of basaloid myoepithelial cells that was exclusively found in BCA cases, and $52 \%$ of BCA cases had activating mutations of the CTNNB1 gene [2]. Our results were consistent with the findings of previous reports regarding the nuclear expression of $\beta$-catenin and mutation of the CTNNB1 gene identified in 74 and $34 \%$ of BCA cases, respectively; however, our mutation detection rate was slightly lower than their findings $[2,3,8]$.

By contrast, the BCAC cases showed TLE1 staining for luminal cells, similar to that in BCA, in non-infiltrative areas but indistinct staining in infiltrative areas. BCAC is considered to arise mostly de novo or to progress from $\mathrm{BCA}$ in some cases $[4,5,10]$. TLE1 staining revealed antecedent BCA areas in all cases of BCAC. In this study, we could identify the BCAC, which some authors recognized as carcinoma ex monomorphic adenoma, carcinoma in basal cell adenoma, and $\mathrm{BCAC}$ evolution from a preexisting $\mathrm{BCA}[5,10]$. In $\mathrm{BCAC}$, the obscure expression of TLE1 in infiltrative areas might suggest that these areas shifted the Wnt/ $\beta$-catenin signaling pathway to the "on" state compared with non-infiltrative areas, resulting in malignancy characteristics such as invasion. Indistinct staining of $\alpha$ SMA lining myoepithelial cells in the invasive lesions supported this suggestion because the surrounding myoepithelial cells were considered tumor suppressors

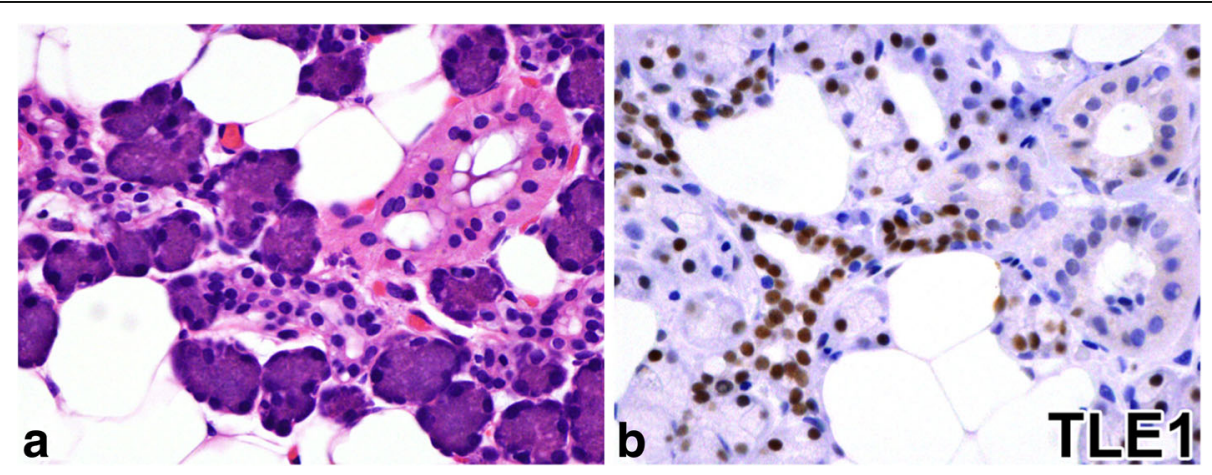

Fig. 1 Normal salivary glands (a: hematoxylin-eosin staining, b: immunostaining for TLE1). Normal salivary gland forms ducto-acinar units composed of acini, intercalated ducts, striated ducts, and excretory ducts (a). Acinic cells and intercalated ductal cells are positive, and myoepithelial cells and excretory ductal cells are negative for TLE1 (b) 

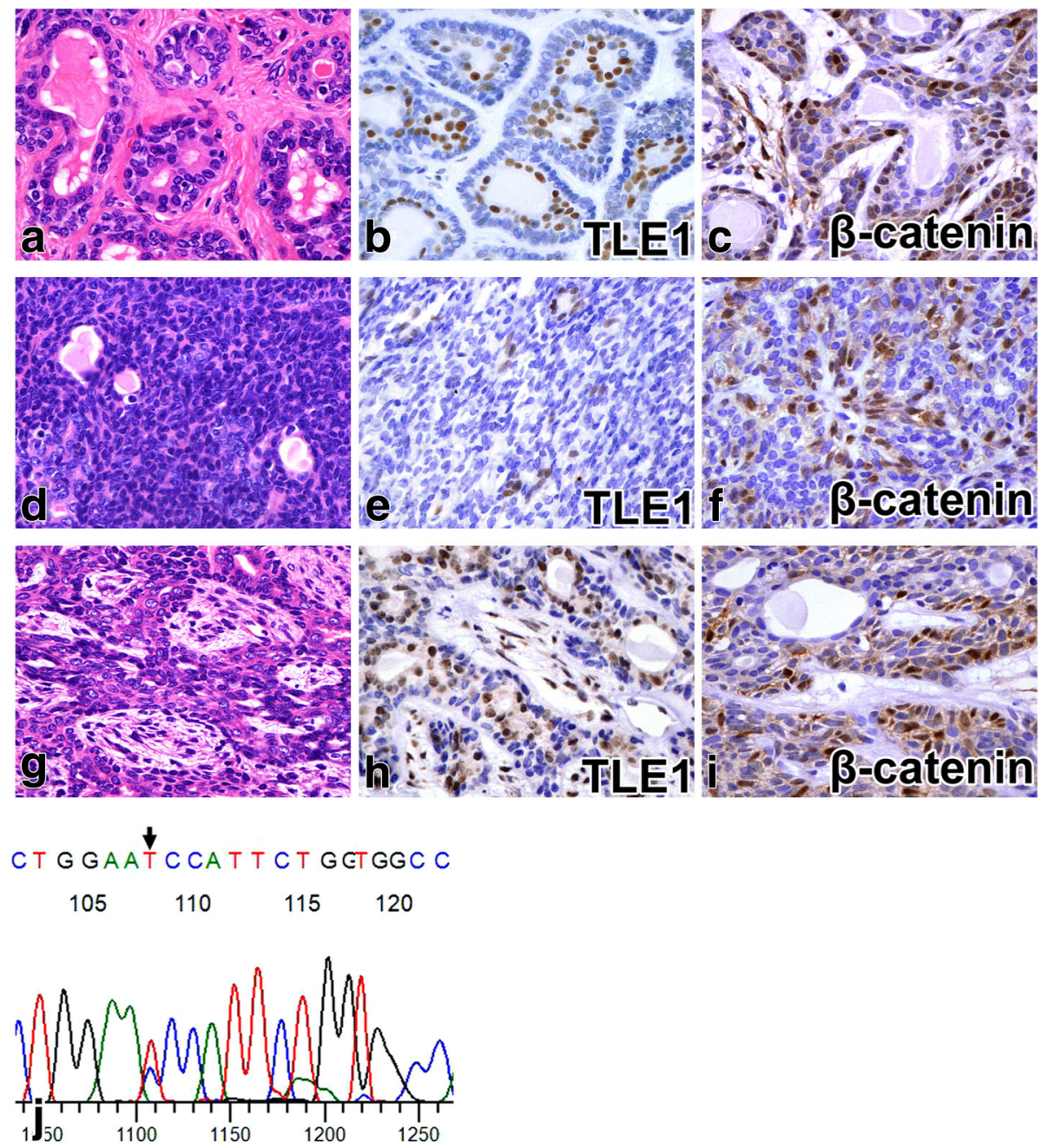

Fig. 2 Basal cell adenoma (BCA). BCA of tubular (a-c), solid (d-f), trabecular ( $\mathbf{g - i})$ growth patterns with hematoxylin-eosin staining $(\mathbf{a}$, $\mathbf{d}$, and $\mathbf{g})$, TLE1 (b, e, and $\mathbf{h}$ ), and $\beta$-catenin (c, $\mathbf{f}$, and $\mathbf{i})$ immunostaining, respectively, are shown. Luminal cells are positive for TLE1 (b, e, and $\mathbf{h})$. Abluminal cells are positive for $\beta$-catenin (c, $\mathbf{f}$, and $\mathbf{i}$ ) in contrast to staining for TLE1. Mutational analysis for CTNNB1 found an exon 3 mutation in $34 \%$ of basal cell adenomas (j, BCA case 10)

and were seen in both benign and in-situ salivary gland neoplasms but were rarely found in invasive neoplasms [18]. In $\mathrm{BCAC}$, the nuclear expression of $\beta$-catenin in abluminal cells could be seen in both areas, and $50.0 \%(2 / 4)$ of the cases had CTNNB1 gene mutations. The LCM allowed the separate collection of infiltrative and non-infiltrative areas, and this is the first report to document the same mutation of the CTNNB1 gene in both areas. This finding strengthened the secondary theory and indicated that the adenoma-carcinoma sequence existed between BCA and BCAC.

Several features and immunohistochemical markers of preferentially suggestive BCAC have been proposed, although many of them remain ancillary observations [5-7]. BCAC displays various growth patterns (tubular, trabecular, solid), similar to BCA; however, many authors noted that solid patterns were frequently seen in BCAC cases
$[5-7,10]$. Nagao et al. found that BCAC cases showed increased mitotic figures (>4/10 HPF) and a Ki67 LI (> 5\%), and Wilson et al. suggested that mitotic rates above 3 per $10 \mathrm{HPF}$ were more correlated with BCACs cases $[5,7]$. Most of our BCAC cases showed solid growth patterns $(3 / 4,75 \%)$ and satisfied the condition of an increased mitotic count (> 3/10 HPF) and a Ki67 LI (> 5\%). These findings are optional but helpful for identifying BCAC. Staining for TLE1 can be an additional approach for differentiating $\mathrm{BCAC}$ from $\mathrm{BCA}$, especially indistinct luminal cell expression for TLE1 in invasive areas of BCAC.

Our study has limitations. The number of BCAC cases was small. Further studies are warranted to confirm the utility of TLE1 immunohistochemistry in salivary gland tumors. 

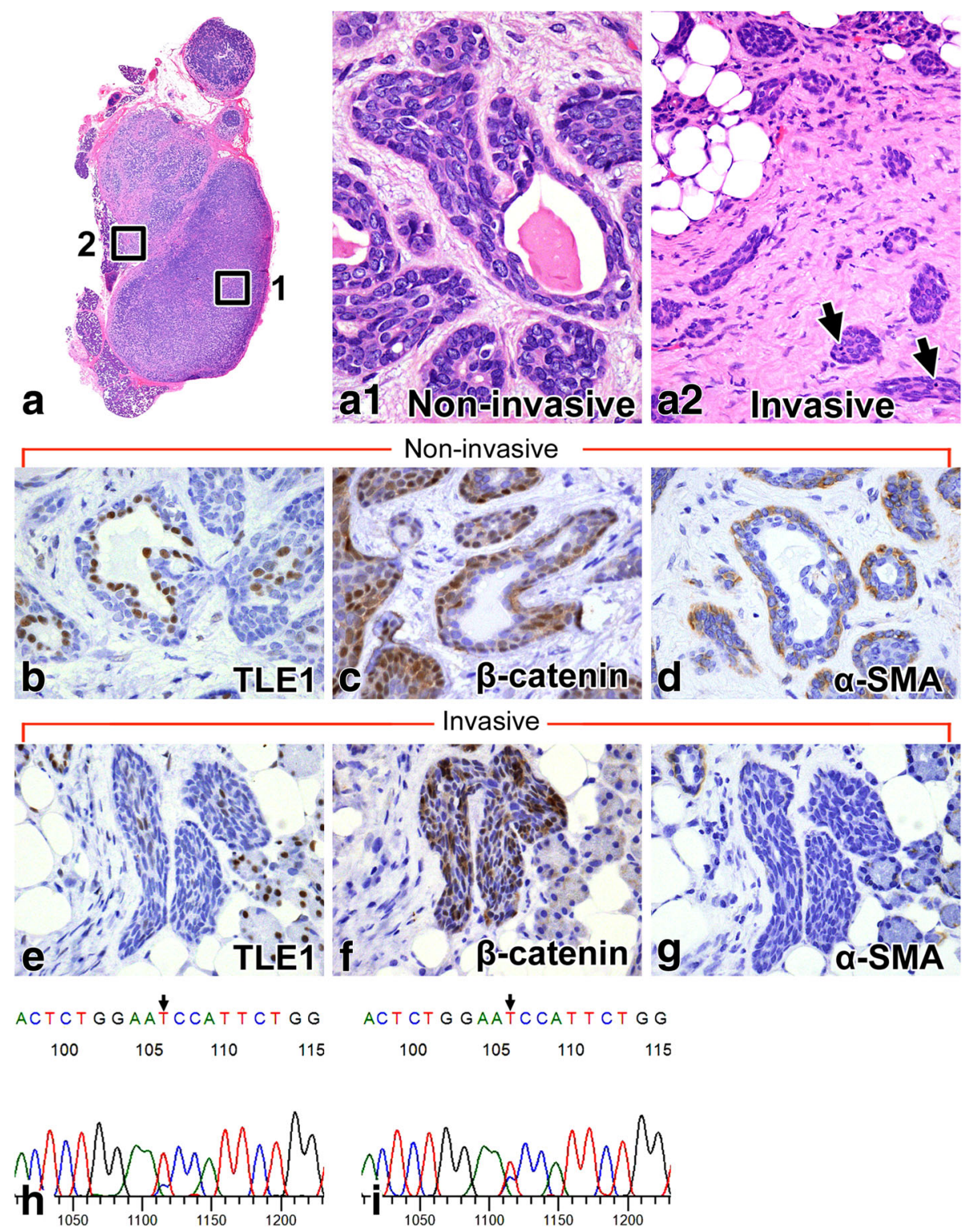

Fig. 3 Basal cell adenocarcinoma (BCAC). BCAC histology (a: low magnification, a1: high magnification of square 1, a2: high magnification of square 2) with hematoxylin-eosin staining are shown. A multinodular tumor (a) forms a tubular, trabecular, solid growth pattern in non-invasive areas (a1), and small tumor nests infiltrate the surrounding parenchyma (a2). They show slightly increased mitotic activity (arrows in a2). BCAC of non-invasive areas (b-d) and invasive areas $(\mathbf{e}-\mathbf{g})$ with $\operatorname{TLE} 1(\mathbf{b}, \mathbf{e}), \beta$-catenin $(\mathbf{c}, \mathbf{f})$, and $\mathbf{a}-\mathrm{SMA}(\mathbf{d}, \mathbf{g})$ immunostaining, respectively, are shown. In non-invasive areas, luminal cells are positive for TLE1 (b), abluminal cells are positive for $\beta$-catenin(c), and the lining of myoepithelial cells are positive for a-SMA(d). In invasive areas, luminal cells staining for TLE1 (e) becomes indistinct, abluminal cells positivity for $\beta$-catenin(f) remains unchanged, and the a-SMA(g) lining myoepithelial cells disappear. Mutational analysis for CTNNB1 detected the same mutation on both areas of the tumor (h: non-invasive areas, i: invasive areas, BCAC case 1)

\section{Conclusion}

In conclusion, we successfully investigated the TLE1 and $\beta$-catenin expression profiles and the CTNNB1 gene mutational status among BCA and BCAC cases. In BCA cases, TLE1 showed staining in luminal cells in contrast to $\beta$-catenin staining in abluminal cells. In BCAC, TLE1 showed luminal cell staining in non-infiltrative areas and indistinct staining in infiltrative areas. CTNNB1 mutations were found in $34 \%$ of the BCA cases, $50 \%$ of the
BCAC cases. We furthermore demonstrated the same mutation found in non-invasive and invasive areas in $\mathrm{BCAC}$ and indicated that the adenoma-carcinoma sequence exsisted between BCA and BCAC. Immunohistochemical analysis for TLE1 can help identify BCA and $\mathrm{BCAC}$ from its luminal cell staining difference, especially indistinct luminal cell expression for TLE1 in invasive areas of BCAC. Moreover, TLE1 can be luminal/ductal cell markers. 


\section{Abbreviations}

BCA: Basal cell adenoma; BCAC: Basal cell adenocarcinoma; BCN: Basal cell neoplasm; CTNNB1: Catenin-beta 1; FFPE: Formalin-fixed paraffin embedded; HDAC: Histone deacetylase; HER2: Human epidermal growth-factor receptor 2; HPF: High power fields; LCM: Laser-capture microdissection; LEF: Lymphoid enhancer factor; LI: Labeling index; TCF: T-cell factor; TLE1: Transducin-like enhancer of split 1

\section{Availability of data and materials}

The data sets used and/or analyzed during the current study are available from the corresponding author on reasonable request.

\section{Authors' contributions}

YO substantially contributed to the conception or design of this work; HN, TK, and TD drafted the work or revised it critically for important intellectual content; HK, MA, JW, SU, TH, KK, MS, SY supported the research. All authors have read and approved the final version to be published.

\section{Ethics approval and consent to participate}

Our study was carried out according to the ethical guideline of the Declaration of Helsinki (as revised in 2013 in Brazil) and was approved by the institutional review board of Oita University Hospital and Oita Prefecture Hospital (the reference number 1298) and was approved the study did not require additional informed consent for our retrospective study.

\section{Consent for publication}

Not applicable.

\section{Competing interests}

The authors declare that they have no competing interests.

\section{Publisher's Note}

Springer Nature remains neutral with regard to jurisdictional claims in published maps and institutional affiliations.

\section{Author details}

'Department of Diagnostic Pathology, Faculty of Medicine, Oita University, 1-1, Idaigaoka, Hasama-machi, Yufu 879-5593, Japan. ${ }^{2}$ Oita Preferectual Hospital, Oita, Japan. ${ }^{3}$ Department of Otolaryngology, Faculty of Medicine, Oita University, Yufu, Japan. ${ }^{4}$ Department of Oral and Maxillofacial Surgery, Faculty of Medicine, Oita University, Yufu, Japan.

Received: 2 April 2018 Accepted: 18 July 2018

Published online: 27 July 2018

\section{References}

1. Li J, Fonsera I. Basal cell adenoma. In: Ei-Nagger AK, JKC C, Grandis JR, Takata T, Slootweg PJ, editors. WHO classification of head and neck tumors. Lyon: IARC Press; 2017. p. 187-8.

2. Kawahara $\mathrm{A}$, Harada $\mathrm{H}$, Abe $\mathrm{H}$, et al. Nuclear $\beta$-catenin expression in basal adenomas of salivary gland. J Oral Pathol Med. 2011:40:460-6.

3. Wilson TC, Ma D, Tilak A, et al. Next-generation sequencing in salivary gland basal cell adenocarcinoma and basal cell adenoma. Head Neck Pathol. 2016; 10:494-500.

4. Fonsera I, Gnepp DR, Seethala R, et al. Basal cell adenocarcinoma. In: EiNagger AK, JKC C, Grandis JR, et al., editors. WHO classification of head and neck tumors. Lyon: IARC Press; 2017. p. 169-70.

5. Nagao T, Sugano I, Ishida $Y$, et al. Basal cell adenocarcinoma of salivary glands: comparison with basal cell adenoma through assessment of cell proliferation, apoptosis, and expression of p53 and bcl-2. Cancer. 1998; 82:439-47.

6. Jung MJ, Roh JL, Choi SH, et al. Basal cell adenocarcinoma of the salivary gland: a morphological and immunohistochemical comparison with basal cell adenoma with and without capsular invasion. Diagn Pathol. 2013:8:171.

7. Wilson TC, Robinson RA. Basal cell adenocarcinoma and basal cell adenoma of the salivary glands: a clinicopathological review of seventy tumors with comparison of morphologic features and growth control index. Head Neck Pathol. 2015:9:205-13.

8. Jo VY, Sholl LM, Krane JF. Distinctive patterns of CTNNB1 ( $\beta$-catenin) alterations in salivary gland basal cell adenoma and basal cell adenocarcinoma. Am J Surg Pathol. 2016:40:1143-50.
9. Zhan KY, Lentsch EJ. Basal cell adenocarcinoma of the major salivary glands: a population-level study of 509 cases. Laryngoscope. 2016;126:1086-90.

10. Muller $S$, Barnes $L$. Basal cell adenocarcinoma of the salivary glands: report of seven cases and review of the literature. Cancer. 1996;78:2471-7.

11. Lee $\mathrm{JH}$, Bae SB, Oh MH, et al. Clinicopathologic and prognostic significance of transducing-like enhancer of split 1 protein expression in invasive breast cancer. J Breast Cancer. 2017;20:45-53.

12. Terry J, Saito T, Subramanian S, et al. TLE1 as a diagnostic immunohistochemical marker for synovial sarcoma emerging from gene expression profiling studies. Am J Surg Pathol. 2007;31:240-6.

13. Cironi L, Petricevic T, Vieira VF, et al. The fusion protein SS18-SSX1 employs core Wnt pathway transcription factors to induce a partial Wnt signature in synovial sarcoma. Sci Rep. 2016;6:22113.

14. Lee JH, Son MW, Kim KJ, et al. Prognostic and clinicopathological significance of transducer-like enhancer of split 1 expression in gastric cancer. J Gastric Cancer. 2016;16(1):364-71.

15. Daniels DL, Weis WL. Beta-catenin directly displaces Groucho/TLE repressors from Tcf/Lef in Wnt-mediated transcription activation. Nat Struct Mol Biol. 2005;12(4):364-71

16. Hai B, Yang Z, Milar SE, et al. Wnt/ $\beta$-catenin signaling regulates postnatal development and regeneration of the salivary gland. Stem Cells Dev. 2010; 19(11):1793-801.

17. Queimado L, Obeso D, Hatfield MD, et al. Dysregulation of Wnt pathway components in human salivary gland tumors. Arch Otolaryngol Head Neck Surg. 2008;134(1):94-101.

18. Shah AA, Mulla AF, Mayank M. Pathophysiology of myoepithelial cells in salivary glands. J Oral Maxillofac Pathol. 2016;20:480-90.

\section{Ready to submit your research? Choose BMC and benefit from:}

- fast, convenient online submission

- thorough peer review by experienced researchers in your field

- rapid publication on acceptance

- support for research data, including large and complex data types

- gold Open Access which fosters wider collaboration and increased citations

- maximum visibility for your research: over $100 \mathrm{M}$ website views per year

At $\mathrm{BMC}$, research is always in progress.

Learn more biomedcentral.com/submissions 